\title{
Entrepreneurship and factors of Intention among Omanis
}

\author{
Dr. Subrahmanian Muthuraman, Dr. Mohammed Al-Haziaz², Dr. \\ Rengarajan Veerasamy ${ }^{3}$, Dr. Nasser Al Yahyaei ${ }^{4}$ \\ 1,2,3,4 Faculty of Business Studies, Arab Open University, Muscat, Sultanate of Oman
}

\begin{abstract}
Oman Vision 2040 has a specific emphasis on entrepreneurship development. High quality of entrepreneurial activities, at present generates positive impact on nationals and subsequently determines an improvement on the business environment. The strategy has laid the development of the new enterprise in its priorities to diversify the national economy and reduce its heavy reliance on oil that is witnessing greater price volatility in the global market. The study attempts to assess entrepreneurial intentions among Omanis in relation to independent variable such as personal attitude, professional attraction, subjective norms, and perceived behavior control. A structured questionnaire was used to collect data from 174 young Omanis from the Sultanate of Oman and was analyzed with Chi Square, Pearson Correlation Test, Spearman Correlation Test_and Multiple Linear Regression. However, it is revealed that the regression model is a good fit of the data. There is an increase, and interest amongst the Omanis with respect to entrepreneurship and innovation. The study shall recommend that the focus of government programs should be supporting new entrepreneurs to reach out to global markets, and to extend support to accelerate small business, support, and sustain them. The government should realize the aspirant entrepreneur ambitions to develop a holistic strategy with very clear pathways, outputs, KPIs, and collaborate with other SME ecosystem and key stakeholders to achieve Oman Vision 2040 goals.
\end{abstract}

\section{Key Words}

Entrepreneurship, Intention, Attitude, Behavior, Ambition

\section{Introduction}

Entrepreneur paves the way to industrialization; industrialization strategies could better target high-potential entrepreneurial activities to accelerate industrialization (Omoruyi et al., 2017). Entrepreneurship plays a significant role in national economies around the world, including the Sultanate of Oman. Entrepreneurship in Oman is set as a key goal to support the economy to emphasize the development and the outcome of its SME. The Sultanate of Oman; moreover, aims to diversify from the current main sources of income and development, which are oil and gas, to cope with the increasing challenges, nowadays related to the growth of population and youth unemployment. (Al-Abri, et al, 2018). "The National Economy of a country is in fact based on small and medium industries these are the fundamentals, the foundations of all national economies" (Ryada, 2018). In the Sultanate of Oman, this step was taken to gradually help SME Sector to become major contributor to the Oman national economy (Al Barwani et al., 2014). According to GEM (2020) Entrepreneurial Activity Review, Oman's measures of 
entrepreneurial activity in 2020 reflect an economy clearly impacted by the COVID-19 pandemic; however, simultaneously, the pandemic appears to be driving less of that activity than might be expected. Oman Vision 2040 has a specific emphasis on entrepreneurship development and is the key to the long-term economic growth of the country. (Muthuraman et al., 2021)

\section{Literature Review}

Global entrepreneurship Monitor (GEM) defines entrepreneurship as "any attempt at new business or new venture creation, such as self-employment, a new business organization, or the expansion of an existing business, by an individual, a team of individuals or an established business (Kelley, Singer et al. 2012). Entrepreneurship focuses on economic growth, economic competitiveness, job creation, as well as improvement of social welfare in any country (Fatoki 2011).

Evidence shows that when jobs are less, especially youth are generally more likely to be unemployed. Economic crisis crippling the job market, young people are first to be laid off. This has led to thousands of laid off workers returning to rural areas where the chances for getting alternative work are dire. Therefore, many young people are compelled to be selfemployed and becoming "entrepreneurs by necessity" rather than "entrepreneurs by choice" (Muthuraman \& Al Haziazi, 2019). Development of entrepreneur and enterprise is a vital part of entrepreneurship development through entrepreneurship process (Melwani, 2018). The development of entrepreneurship is one of the sources of economic development. The concept of entrepreneurial development is to prepare a person with essential knowledge and information that are required for building the enterprise and shine his entrepreneurial skills (Muthuraman, et al, 2020). The economic growth of a country depends on the number of entrepreneurs present in that country as well as on a favorable social-economic environment of that country (Kumar \& Raj, 2019).

\section{Purpose \& Methodology}

In Oman entrepreneurship have earned recognition from the government (Oman daily, 2001). This is because of their importance in generating new jobs, developing local resources, and playing an important complementary role to large firms (Al Markazi, 2001). By reinforcing economic growth and development, entrepreneurs help to create a more prosperous society, thus improving the nation's well-being. The high priority given to promoting entrepreneurship in Oman is not just because of the above-mentioned contributions, but also more significantly due to Oman industrial structure (Muthuraman \& Al Haziazi, 2019). The strategy has laid the development of the SMEs sector in its priorities to diversify the national economy and reduce its heavy reliance on oil that is witnessing greater price volatility in the global market (Alqassabi, 2020). 


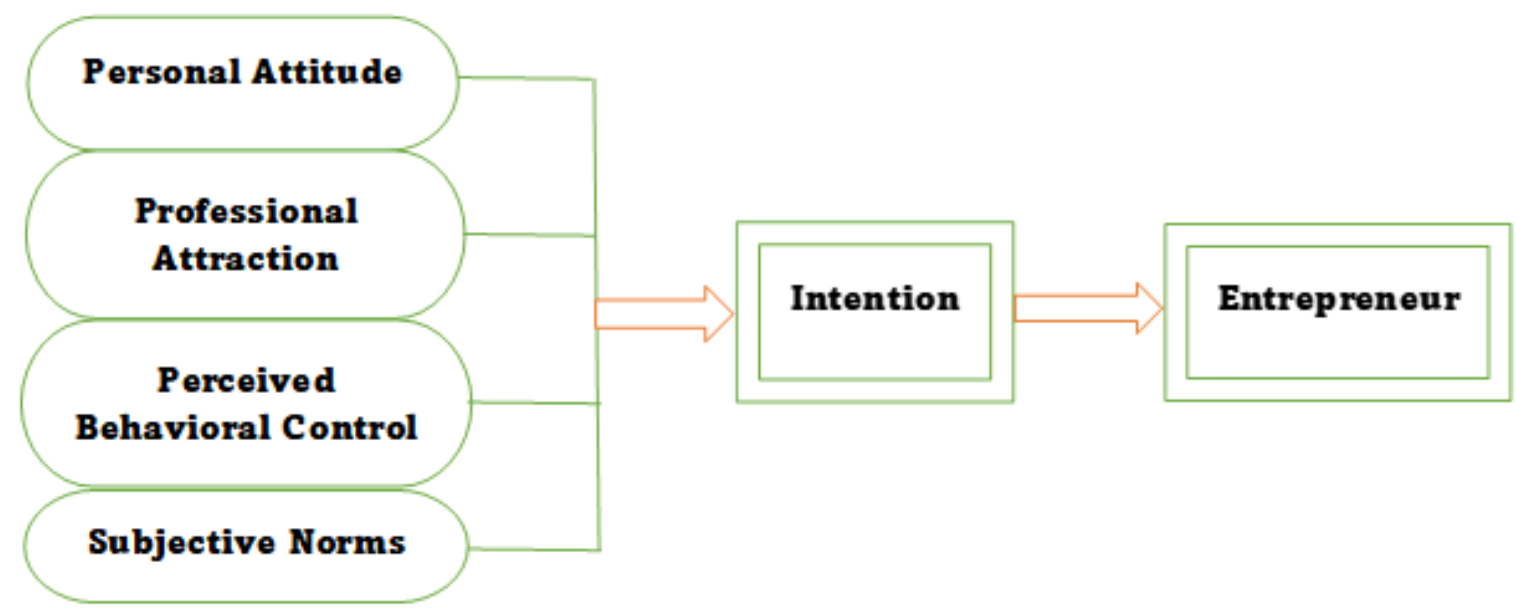

The focus of this research is to assess entrepreneurial intentions among Omanis in relation to its factors such as personal attitude, professional attraction, subjective norms, and perceived behavior control. The post tested survey questionnaire was developed in conjunction with the literature review aimed at understanding respondents' perception and attitude towards entrepreneurial intent. The study adopted the survey research design using structured questionnaire that collects demographic data and entrepreneurial intent through professional attraction, personal attitude, subjective norms, and perceived behavior control among Omanis.

The questionnaire was developed to assess factors influencing entrepreneurial intentions among Omanis through professional attraction, personal attitude, subjective norms, and perceived behavior control. Few questions on demographic variable and entrepreneurial intention were added. The respondents were required to indicate their opinion on each statement on a seven-point scale: $1=$ total disagreement to $7=$ total agreement. The questionnaire was submitted to the experts in the field of Entrepreneurship and based on their feedback minor changes has been made on the questionnaire and distributed to few samples' population for the pilot study and the reliability was calculated with the help of Cronbach alpha (Hair et al., 1998). Cronbach Alpha value was found to be 0.741 and the total numbers of questions were 26 . The values were found to be in the range of 0.60 and 0.90 , hence it might be suggested that all the scales met the reliability condition (Hair et al., 1998, p.118).

The survey population of this study consists of young Omanis who are interested to become entrepreneurs. Convenience sampling method was used to draw 200 samples in Muscat, Oman. The respondents were clearly explained about the purpose of this research before collecting data. Due to some limitations, 185 completed questionnaires were returned, but accuracy is not compromised, all the samples were thoroughly evaluated and on the other hand it was found that there were few errors in 11 samples; they were not valid, so it got removed and finally 174 samples were taken for the final analysis. 


\section{Result \& Discussion}

The data that was collected for this study was processed manually through coding and then entered electronically. The Microsoft Excel and Statistical package for Social Sciences (SPSS) were used for the analysis. The use of statistical distributions such as tables showing frequencies and percentages were adopted in the study. The hypotheses stated in the study were analyzed with the help of Chi Square, Pearson Correlation Test, Spearman Correlation Test and Multiple Linear Regression.

\section{Demographic Analysis}

Chart 1 presents the demographics data based on age, education, and gender of respondents with their description range and frequency

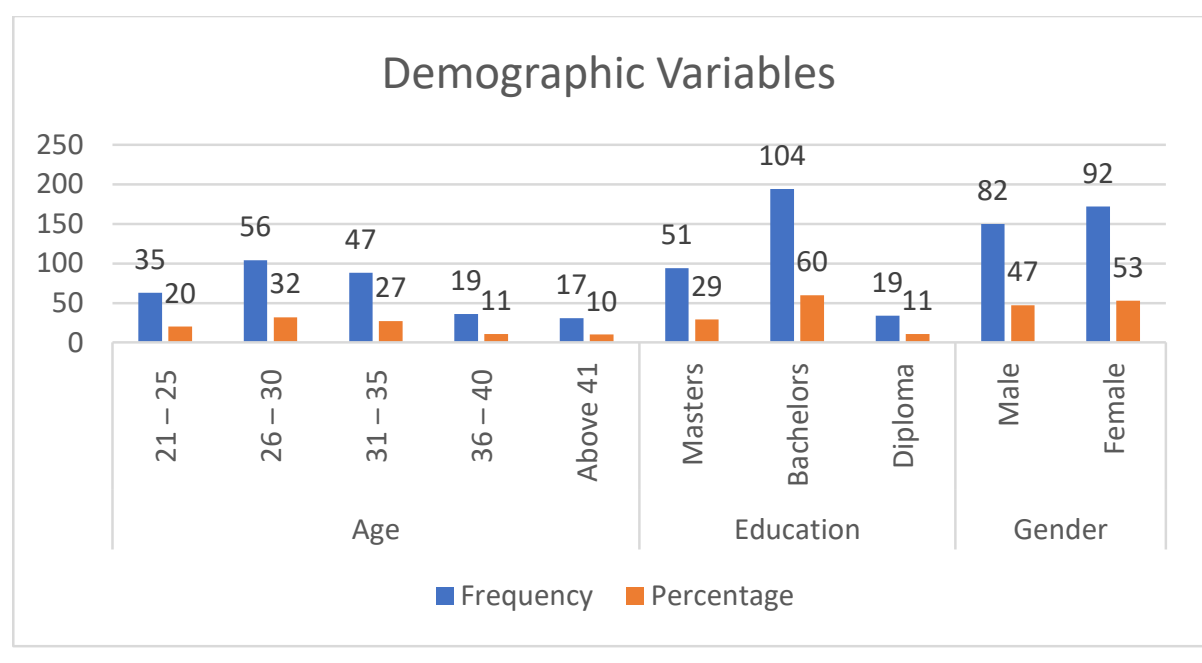

The analysis reveals that $32 \%$ of the respondents were in the age group of $26-30,27 \%$ fall between the age bar of $31-35$ and $20 \%$ fall between the age bars of $21-25,11 \%$ of the respondent fall between $36-40$ and the remaining $10 \%$ of the respondent fall in the age group of above 41 . In respect to the education of the respondents, $60 \%$ of them are bachelors, $29 \%$ of them were master's and the remaining $11 \%$ were diploma holders. In respect to the gender, $53 \%$ of the respondents were female and the remaining $47 \%$ of the respondents were male.

Table 1 Pearson Correlation Test

Table 1 shows A Pearson correlation analysis was conducted between Personal Attitude and Entrepreneurial Intention

\begin{tabular}{|l|l|r|r|}
\hline \multicolumn{4}{|c|}{ Correlations } \\
\hline \multicolumn{1}{|c|}{} & Personal Attitude & Entrepreneurial Intention \\
\hline Personal Attitude & Pearson Correlation & 1 & .124 \\
\cline { 2 - 4 } & Sig. (2-tailed) & & .027 \\
\cline { 2 - 4 } & $\mathrm{N}$ & 174 & 174 \\
\hline Entrepreneurial Intention & Pearson Correlation & $.124^{*}$ & 174 \\
\cline { 2 - 4 } & Sig. (2-tailed) & .027 & 174 \\
\cline { 2 - 5 } & $\mathrm{N}$ & & \\
\hline \multirow{2}{*}{$*$ Correlation is significant at the 0.05 level (2-tailed). } & & \\
\hline
\end{tabular}


The test of Pearson correlation was performed for Personal Attitude and Entrepreneurial Intention

Table 1 shows the output of the Pearson correlation tests of Personal Attitude and Entrepreneurial Intention are inter-correlated. Findings show that there were positive and strong relationships between Personal Attitude and Entrepreneurial Intention.

\section{Table 2 Spearman Correlation Test}

Table 2 shows Spearman correlation analysis was conducted between Personal Attitude and Perceived Behavioral Control

\begin{tabular}{|l|l|l|r|r|}
\hline \multicolumn{5}{|c|}{ Correlations } \\
\hline \multicolumn{2}{|c|}{$\begin{array}{l}\text { Spearman's } \\
\text { rho }\end{array}$} & Personal Attitude & Personal Attitude & Perceived behavioral control \\
\cline { 3 - 5 } & & 1.000 & .025 \\
\cline { 3 - 5 } & & & & .658 \\
\cline { 2 - 5 } & Sig. (2-tailed) & 174 & 174 \\
\cline { 2 - 5 } & Perceived & Correlation Coefficient & .025 & 1.000 \\
\cline { 3 - 5 } & behavioral control & Sig. (2-tailed) & .658 & 174 \\
\cline { 2 - 5 } & & N & 174 & \\
\hline
\end{tabular}

The test of Spearman correlation was performed for Personal Attitude and Perceived Behavioral Control Table 2 shows the output of the Spearman correlation tests of Personal Attitude and Perceived Behavioral Control are inter-correlated. Results show that there were positive and strong relationships between Personal Attitude and Perceived Behavioral Control. Chi Square Test

Chi Square test was conducted to find out the significant association of Personal Attitude with Subjective Norms and Perceived Behavioral Control (Refer Table 3 \& 4)

Table 3 Chi-Square Tests to find the significant association between Personal Attitude and Professional Attraction

\begin{tabular}{|l|r|r|}
\hline \multicolumn{3}{|c|}{ Test Statistics } \\
\hline & \multicolumn{1}{|c|}{ Personal Attitude } & \multicolumn{1}{|c|}{ Professional Attraction } \\
\hline Chi-Square & $142.621^{\mathrm{a}}$ & $98.857^{\mathrm{a}}$ \\
\hline df & 3 & 3 \\
\hline Asymp. Sig. & .000 & .000 \\
\hline N of Valid Cases 174 & \\
\hline a. 0 cells (0.0\%) have expected frequencies less than 5. The minimum expected cell frequency is 80.5. \\
\hline
\end{tabular}

The Chi Square Test was conducted to find the significant association between Personal Attitude and Professional Attraction. Table shows the output of Chi Square Test which shows that the P Value is 0.000 . There is a statistically significant association between Personal Attitude and Professional Attraction. 
Table 4 Chi-Square Tests to find the significant association between Personal Attitude and Subjective Norms

\begin{tabular}{|l|r|r|}
\hline \multicolumn{3}{|c|}{ Test Statistics } \\
\hline & Personal Attitude & Subjective Norms \\
\hline Chi-Square & $142.621^{2}$ & $123.765^{2}$ \\
\hline df & 3 & 3 \\
\hline Asymp. Sig. & .000 & .000 \\
\hline N of Valid Cases 174 & \multicolumn{2}{|c|}{} \\
\hline a. 0 cells $(0.0 \%)$ have expected frequencies less than 5. The minimum expected cell frequency is 80.5. \\
\hline
\end{tabular}

The Chi Square Test was conducted to find the significant association between Personal Attitude and Subjective Norms Table shows the output of Chi Square Test which shows that the $\mathrm{P}$ Value is 0.000 . There is a statistically significant association between Personal Attitude and Subjective Norms.

\section{Multiple Liner Regression}

In this study the researcher tried linear regression is an approach for modeling the relationship between a scalar dependent variable Entrepreneurial Intention and one or more explanatory variables (or independent variables) Perceived behavioral control, Personal Attitude, Subjective norm, Professional attraction.

\section{Table 5. Multiple Liner Regression - Model Summary}

The table of interest is the Model Summary table, as shown below

\begin{tabular}{|l|r|r|r|rr|}
\hline Model & $\mathrm{R}$ & \multicolumn{1}{c|}{ R Square } & Adjusted R Square & \multicolumn{2}{|c|}{ Std. Error of the Estimate } \\
\hline 1 & $.309^{9}$ & .095 & .084 & .79499 \\
\hline $\begin{array}{l}\text { a. Predictors: (Constant), perceived behavioral control, Personal } \\
\text { Professional attraction }\end{array}$
\end{tabular}

The above table provides the $\mathrm{R}$ and $\mathrm{R}^{2}$ values. The $\mathrm{R}$ value represents the simple correlation and is 0.309 (the " $\mathrm{R}$ " Column), which indicates a moderate degree of correlation. The $\mathrm{R}^{2}$ value (the "R Square" column) which is the proportion of variance in the dependent variable, Entrepreneurial Intention that can be explained by the independent variables such as Perceived behavioral control, Personal Attitude, Subjective norm, Professional attraction. (Technically, it is the proportion of variation accounted for by the regression model above and beyond the mean model). It is inferred that the value is 0.095 that the independent variables explain $9.5 \%$ of the variability of the dependent variable. 
Table 6. Multiple Liner Regression - ANOVAa

The next table is the ANOVA table, which reports how well the regression equation fits the data (i.e., predicts the dependent variable) and is shown below:

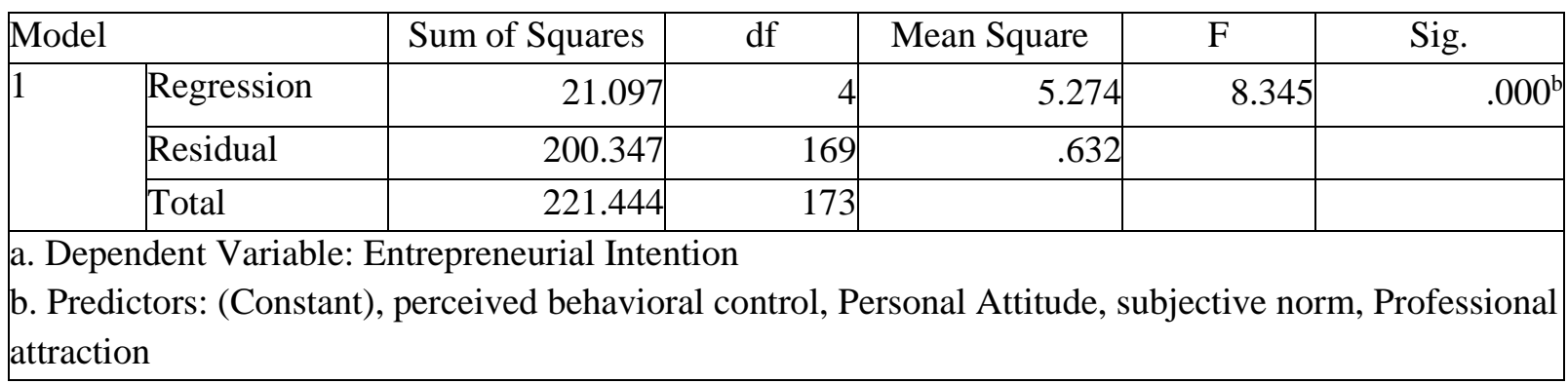

The above table indicates that the regression model predicts the dependent variable significantly well. $\mathrm{P}<0.0005$, which is less than 0.05 , and indicates that, overall, the regression model statistically significantly predicts the outcome variable (i.e., it is a good fit for the data).

\section{Table 7. Multiple Linear Regression - Coefficients (a)}

The Coefficients table provides the necessary information to predict Entrepreneurial Intention, from Perceived behavioral control, Personal Attitude, Subjective norm, Professional attraction, as well as determine whether Perceived behavioral control, Personal Attitude, Subjective norm, Professional attraction contributes statistically significantly to the model.

\begin{tabular}{|c|c|c|c|c|c|}
\hline \multicolumn{6}{|c|}{ Coefficients $^{\mathbf{a}}$} \\
\hline \multirow[b]{2}{*}{ Model } & \multicolumn{2}{|c|}{ Unstandardized Coefficients } & \multirow{2}{*}{$\begin{array}{c}\text { Standardized } \\
\text { Coefficients }\end{array}$} & \multirow[b]{2}{*}{$\mathrm{t}$} & \multirow[b]{2}{*}{ Sig. } \\
\hline & \begin{tabular}{c|}
$\mathrm{B}$ \\
\end{tabular} & Std. Error & & & \\
\hline \begin{tabular}{|l|l|}
1 & (Constant)
\end{tabular} & 4.390 & .432 & & 10.168 & .000 \\
\hline Personal Attitude & .103 & .058 & .095 & 1.769 & .078 \\
\hline Professional attraction & -.108 & .053 & -.119 & -2.011 & .045 \\
\hline Subjective norm & .215 & .043 & .296 & 5.029 & .000 \\
\hline Perceived behavioral control & -.132 & .057 & -.125 & -2.297 & .022 \\
\hline
\end{tabular}

The variables are explained below:

1. Dependent Variable : Entrepreneurial Intention

2. Independent Variable :

a. Personal Attitude

b. Professional attraction

c. Subjective norm X3

d. Perceived behavioral control

\section{X4}

to present the regression equation as:

$$
Y=4.390+0.103 \times 1-0.108 \times 2+0.215 \times 3-0.132 \times 4
$$


From the equation, it is understood that the improvement in Personal Attitude and Subjective Norm (positive values) $0.103 \& 0.215$ has an impact towards entrepreneurial intention and at the same time there is needs more improvement in Professional attraction and Perceived Behavior Control (negative values) $-0.108 \&-0.132$ respectively.

A multiple linear regression was run to predict Entrepreneurial intention from perceived behavioral control, Personal Attitude, subjective norm, Professional attraction. These variables statistically significantly predicted, $\mathrm{F}(4,317)=8.345, \mathrm{P}<.005, \mathrm{R} 2=.0 .95$. All four variables added statistically significantly to the prediction, $\mathrm{P}<.05$ (i.e., the regression model is a good fit of the data).

\section{Implication}

Considering the present research findings presented earlier, several implications are derived. The multiple linear regression results evidence that personal attitudes, professional attraction, subjective norms, and perceived behavioral control effectively predicts entrepreneurial intent significantly. The results also have valuable implications for the authorities and government.

The Sultanate of Oman demonstrated a high cultural affinity for entrepreneurship in 2019. The estimated indicators in this section revealed that almost $85 \%$ of the Omani adults consider starting a business is a good career choice, while about $86 \%$ believe that entrepreneurs are well regarded and enjoy high status within the society (GEM, 2020). Oman have been inspired to generate innovative business ideas or new products through novel experiences and originality. However, they do not possess the elements of opportunism and proactivity, to transform these ideas into effective entrepreneurial activity.

According to the "Mapping the SME Ecosystem in Oman" report published by The Public Authority for SME Development (Riyada, 2018) that supports programs in Oman "highly focused on the early stages of SME creation. Societal attitudes indicate how entrepreneurship is regarded in an economy. Indeed, the unique nature of the Omani culture, traditions, history, and religious experience may all be well reflected in its societal attitude towards entrepreneurship. Omani society shows a high perception of the social values that are important to entrepreneurship initiatives (Al Shukaili, et al, 2019).

In Oman, there is need to increase innovation level with respect to products and/ or processes at international level. One of the strategic pillars of Oman Visions 2020-2040 is to transfer the economy from a traditional to a knowledge-based economy. Therefore, the government is looking to entrepreneurship and innovation as key players in job creation, to support economic diversification and transformation (Al Shukaili, et al, 2019). In Oman there are a wide range of government programs for entrepreneurs which target creativity, innovation, and R\&D. For instance, Innovation Park Muscat and The Research Council were cited in a report about mapping the SME ecosystem in Oman (Al Shukaili, et al, 2019). On the other hand, some experts request from The Public Authority for SME Development to develop a holistic strategy with very clear pathways, outputs, KPIs, and collaborate with other SME ecosystem and key 
stakeholders (Ministries, companies, NGOs, Banks, Funding agencies, incubators) and a clear process for the transfer of R\&D to the private sector to achieve Oman Vision 2040 goals (Al Shukaili, et al, 2019).

There is an increase, and interest amongst the Omanis with respect to entrepreneurship and innovation (Richie, 2018). The focus of government programs should not only be on start-up support but also in innovation, supporting new enterprise to reach out to global markets, and to extend support to accelerate small business, support, and sustain them. Moreover, the government policies and programs should encourage more involvement from all stakeholders within the entrepreneurial ecosystem through good research and technology parks, knowledge clusters, and incubations for new and developing firms (Al Shukaili, et al, 2019). Omani Government may support Omani graduates to realize their entrepreneurial ambitions, contribute to the Omani economy and achieve national inclusion. The government through its ministries may set up an appropriate policy and procedure that would facilitate the creation of new businesses especially amongst youngsters (Subrahmanian, et al, 2017).

\section{Conclusion}

Further to the favorable findings, there exists the limitation in this study, the findings should not be generalized to the much bigger population. The size and type of sample may have been a constraint in this study. However, this study attempts to provide a practical scenario in the Sultanate of Oman, this will help the Government and future researchers and scholars in various aspects and helping them to try a comprehensive study in Oman. The effective contribution to economic and social development is determined by the quality of entrepreneurial activity, rather than the quantity. Entrepreneurial response to pandemic placed it only $30^{\text {th }}$ among GEM economies. This reflects a higher level of confidence in the government, rather than entrepreneurs, to assist Omanis during this time.

\section{Acknowledgement}

This paper is the partial outcome of the project titled "SME \& Economic Development in Sultanate of Oman" ID: BFP/RGP/EHR/18/126 funded by The Research Council (TRC), Sultanate of Oman

\section{Reference}

Al-Abri, M. Y., Rahim, A. A., \& Hussain, N. H. (2018). Entrepreneurial ecosystem: An exploration of the entrepreneurship model for SMEs in Sultanate of Oman. Mediterranean journal of social sciences, 9(6), 193-193.

Al Barwami, K. M., Al-Jahwari, M. R., Al-Saidi, A. S., \& Al Mahrouqi, F. S. (2014). Towards a growing, competitive, and dynamic small and medium-sized enterprises sector in Oman: Strategy and policies. Central Bank of Oman, Economic Research and Statistics Department.

Al-Markazi, (2001). Monthly publication of the Central Bank of Oman, Special Issue (25). 
Al Shukaili, A., Kassim, N., Al Suleimani, B., Zunaith, A., Mondal, S., \& \& Kausar, Y. (2019). Global Entrepreneurship Monitor: Oman National Report 2019. Global Entrepreneurship. Retrieved from www.gemconsortuim.org

Alqassabi, M. A. (2020). Insights on sustainability of small and medium enterprises in oman: a conceptual framework. International Journal of Economics and Financial Issues, 10(1), 209.

Fatoki, O., \& Chindoga, L. (2011). An investigation into the obstacles to youth entrepreneurship in South Africa. International business research, 4(2), 161-169.

GEM Global Report (2020) Entrepreneurial Activity Review, Global Entrepreneurship Research Association, London Business School, UK, https://www.gemconsortium.org/economy-profiles/oman-3/policy

Hair, J.F., Tatham, R.L., Anderson R.E, Black, W, (1998). Multivariate Data Analysis, 4th Edition, Prentice Hall Inc., New Jersey, USA.

Kelley, D. J., Singer, S., \& Herrington, M. D. (2012). The global entrepreneurship monitor: 2011 global report (Vol. 7). GeM.

Kumar, R., \& Raj, T. (2019). Role of Entrepreneurship in Boosting Economic Growth and Employment in India. Small Enterprises Development, Management \& Extension Journal (SEDME), 46(4), 273-281. https://doi.org/10.1177/0970846419894750

Melwani, R. (2018). Entrepreneurship Development and Economic Development: A Literature Analysis. Aweshkar Research Journal, 24(1), 124-149.

Muthuraman, S., Al Haziazi, M., Veerasamy, R., \& Al Yahyaei, N. (2020). Framework for Oman's Economic Development through Small \& Medium Enterprise.

Muthuraman, S., \& Al Haziazi, M. (2019). Entrepreneurial Growth: Challenges to Young Omani Entrepreneurs. International Journal of Business and Applied Social Science, 5(7), 98-114.

Muthuraman, S., Al-Haziaz, M., Veerasamy, R., \& Al Yahyaei, N. (2021, September). Exploration of Entrepreneurship Orientation Among SMEs in the Sultanate of Oman. In European Conference on Innovation and Entrepreneurship (pp. 605-XXV). Academic Conferences International Limited.

Oman daily, (2001), Ministry of Information, Muscat, Oman.

Omoruyi, E. M. M., Olamide, K. S., Gomolemo, G., \& Donath, O. A. (2017). Entrepreneurship and economic growth: Does entrepreneurship bolster economic expansion in Africa. Journal of Socialomics, 6(4), 1-11.

Richie, S. (2018). Inspiring Entrepreneurship in Oman to Achieve Economic Diversification. Entrepreneur Middle East.

Riyada Annual Report, (2018). Public Authority for SME Development (Riyada) Annual Report 2018 (Annual Report). Muscat - Oman.

Subrahmanian, M., Subramanian, K., Al-Haziazi, M., \& Herimon, P. C. S. (2017, September). Entrepreneurial Intent of Prospective Graduates in Sultanate of Oman. In European Conference on Innovation and Entrepreneurship (pp. 653-661). Academic Conferences International Limited. 